Jurnal Keperawatan Silampari

Volume 4, Nomor 2, Juni 2021

e-ISSN: 2581-1975

p-ISSN: 2597-7482

DOI: https://doi.org/10.31539/jks.v4i2.1914

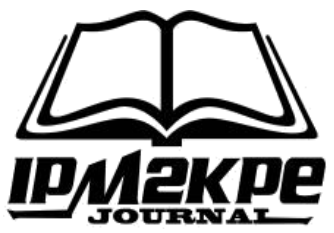

\title{
KEMAMPUAN KEPEMIMPINAN KLINIS PERAWAT PELAKSANA BERDASARKAN PENDEKATAN CLINICAL LEADERSHIP COMPETENCY FRAMEWORK DAN FAKTOR-FAKTOR DETERMINANNYA
}

\author{
Yusnaini ${ }^{1}$, Yulastri Arif ${ }^{2}$, Dorisnita ${ }^{3}$ \\ Sekolah Tinggi Ilmu Kesehatan Nurul Hasanah Kutacane ${ }^{1}$ \\ Universitas Andalas ${ }^{2,3}$ \\ yusnaini84@gmail.com ${ }^{1}$
}

\begin{abstract}
ABSTRAK
Penelitian ini bertujuan untuk menganalisis kemampuan kepemimpinan klinis perawat pelaksana berdasarkan pendekatan clinical leadership competency framework dan faktorfaktor determinannya di ruang rawat inap RSUD Padangsidimpuan. Desain penelitian dalam penelitian ini menggunakan deskriptive analytic corelation. Hasil penelitian menunjukkan ada hubungan bermakna antara ketersediaan sumber daya perawat, dukungan manajemen dan dukungan lingkungan kerja dengan kemampuan kepemimpinan klinis, dengan nilai $\mathrm{p}$ untuk masing-masing variabel yaitu ketersediaan sumber daya perawat $(\mathrm{p}=$ $0,043)$, dukungan manajemen $(\mathrm{p}=0,000)$ dan dukungan lingkungan kerja $(\mathrm{p}=0,005)$. Sedangkan kompetensi tidak ada hubungan bermakna dengan kemampuan kepemimpinan klinis perawat pelaksana di ruang rawat inap RSUD Padangsidimpuan $(p=0,084)$. Analisis multivariat menunjukkan dukungan manajemen merupakan variabel yang paling dominan berhubungan dengan kemampuan kepemimpinan klinis dengan nilai Odds Ratio (OR) 4,476. Simpulan, kemampuan kepemimpinan klinis perawat harus didukung dengan ketersediaan sumber daya perawat, dukungan lingkungan kerja dan dukungan manajemen untuk mendapatkan pelayanan keperawatan yang berkualitas.
\end{abstract}

Kata Kunci: Determinan, Karakteristik Responden, Kepemimpinan Klinis

\begin{abstract}
This study aims to analyze nurses' clinical leadership abilities based on the clinical leadership competency framework approach and its determinants in the inpatient room of Padangsidimpuan Hospital. The research design in this study used a descriptive-analytic correlation. The results showed that there was a significant relationship between the availability of nursing resources, management support, and work environment support with clinical leadership abilities, with a p-value for each variable, namely the availability of nurse resources $(p=0.043)$, management support $(p=0.000)$ and support work environment ( $p=0.005)$. Meanwhile, competence has no significant relationship with nurses' clinical leadership ability in the inpatient room of RSUD Padangsidimpuan ( $p=$ 0.084). Multivariate analysis shows that management support is the most dominant variable associated with clinical leadership skills, with an Odds Ratio (OR) value of 4.476.
\end{abstract}


In conclusion, nurses' clinical leadership ability must be supported by the availability of nurse resources, work environment support, and management support to obtain quality nursing services.

Keywords: Determinants, Respondent Characteristics, Clinical Leadership

\section{PENDAHULUAN}

Perawat dalam memberikan pelayanan keperawatan memerlukan kemampuan kepemimpinan klinis. Kepemimpinan klinis merupakan suatu kompetensi perawat professional dalam pemberian asuhan keperawatan tanpa memandang posisi dalam sistem pelayanan kesehatan (Mianda \& Voce, 2017). Menurut Gatti et al., (2017) kepemimpinan klinis perawat menjadi sumber daya potensial yang digunakan untuk menilai kinerja dalam meningkatkan kesejahteraan bagi perawat dan rumah sakit. Perawat dengan kepemimpinan klinis berfokuskan mempromosikan standar keunggulan dalam profesi keperawatan, meningkatkan kepercayaan publik dan menjamin keselamatan pasien. Oleh karena itu, perawat pelaksana dapat berperan sebagai pemimpin klinis dengan menggunakan kemampuannya dalam memberikan perubahan perawatan.

Perawat pelaksana harus memiliki kemampuan kepemimpinan klinis. Studi Mathumo-Githendu (2018) mengidentifikasi bahwa 50\% perawat baru memiliki keterbatasan pemahaman kepemimpinan klinis terkait pengembangan pribadi yang berkelanjutan, bekerja dalam tim, menerapkan pengetahuan dan bukti serta pengembangan layanan keperawatan. Sedangkan Wright (2020) mendeskripsikan bahwa 3-6\% kepemimpinan klinis perawat kurang baik berdampak pada masalah manajemen asuhan keperawatan. Jadi kemampuan kepemimpinan klinis perawat yang belum optimal harus dikembangkan melalui model kepemimpinan klinis.

Model kepemimpinan klinis menjadi kerangka acuan bagi perawat pelaksana. Clinical Leadership Competency Framework (CLCF) merupakan panduan kepemimpinan klinis yang tepat bagi perawat pelaksana dalam lingkup praktik keperawatan (NHS Improvement, 2019). Menurut Lai et al., (2020) CLCF mendukung perawat dalam memberikan asuhan keperawatan yang terbaik bagi pasien. Studi Nieuwboer et al., (2019) CLCF memfasilitasi perawat melakukan kolaborasi antar profesi kesehatan dalam pemberian layanan kesehatan kepada pasien. Stanley et al., (2017) perawat menggunakan CLCF untuk meningkatkan kemampuan kepemimpinan klinis memberikan pengaruh terhadap perubahan pelayanan keperawatan yang berkualitas.

Klasifikasi CLCF dikelompokan dalam berbagai komponen atau domain. Menurut Health Education England (HEE) \& NHS (2018) CLCF terdiri dari 7 domain kepemimpinan klinis meliputi 5 domain ditujukan untuk perawat pelaksana dan 2 domain tambahan untuk perawat manajer. Adapun 5 domain untuk perawat pelaksana yaitu kualitas diri (personal qualities), kerjasama (working with others), manajemen asuhan keperawatan (managing service), pengembangan layanan (improving service) dan kemampuan change agent (setting direction). Sedangkan 2 domain tambahan untuk perawat manager mencakup menciptakan visi (creating the vision) dan mengembangkan strategi (delivery strategy). Vinu-Job et al., (2020), kerangka kerja CLCF bertujuan membantu perawat memperoleh pengetahuan dan keterampilan yang relevan dalam pengaturan pelayanan keperawatan. Berdasarkan kerangka tersebut, perawat mempunyai konsep yang jelas dalam 
pengembangan kepemimpinan klinis. CLCF mendukung kemampuan individu perawat pelaksana.

Berdasarkan 5 (lima) domain CLCF tersebut, perawat pelaksana menunjukkan kemampuan kepemimpinan klinis. Studi Boamah (2019) memperlihatkan bahwa CLCF menjadi solusi nyata menjamin keselamatan pasien, namun perawat pelaksana kurang menggunakan kemampuan kepemimpinan klinis dalam pemberian perawatan pasien. Schwendimann et al., (2018) mengidentifikasi bahwa Kejadian Tidak Diharapkan (KTD) yang fatal sekitar $10 \%$ dan 34,3\% sampai $83 \%$ dianggap dapat dicegah. Ada tiga KTD yang sering dilaporkan yaitu terkait tindakan operasi/pembedahan, pemberian obat/cairan dan infeksi nasokomial. Hal ini berkaitan dengan kurangnya kemampuan kemimpinan klinis perawat pelaksana dalam menjamin keselamatan pasien selama perawatan. Jadi kemampuan kepemimpinan klinis perawat pelaksana yang belum optimal berakibat untuk terjadinya KTD memiliki kemampuan kepemimpinan klinis.

Pelaksanaan kemampuan kepemimpinan klinis dapat disebabkan oleh berbagai faktor. Menurut Mianda \& Voce (2018) pengembangan kemampuan kepemimpinan klinis perawat pelaksana berkaitan dengan faktor ketersediaan sumber daya perawat, kompetensi, dukungan manajemen dan dukungan lingkungan kerja. Faktor tersebut sangat efektif dalam pengembangan kepemimpinan klinis perawat pelaksana yang berada pada garda terdepan.

Peneliti melakukan studi pendahuluan pada tanggal 3 sampai 6 Februari 2016 terkait 5 domain kepemimpinan klinis perawat pelaksana di RSUD Padangsidimpuan melalui wawancara dan pembagian kuesioner CLCF pada 20 perawat pelaksana. Berdasarkan hasil wawancara dengan kasi bidang keperawatan II RSUD, belum ada studi khusus yang dilakukan tentang kemampuan kepemimpinan klinis perawat pelaksana. Sedangkan hasil pembagian kuesioner CLCF didapatkan bahwa 35\% perawat menyatakan dirinya mempunyai kualitas diri kurang baik, 30\% perawat menyatakan kurang baik dalam melakukan kerjasama, $45 \%$ perawat kurang baik dalam melakukan manajemen asuhan keperawatan, 30\% perawat menyatakan kurang baik dalam pengembangan layanan keperawatan dan $55 \%$ perawat pelaksana kurang baik dalam menjadi change agent.

Beberapa penelitian sebelumnya hanya menganalisis tentang kepemimpinan manajerial saja, sedangkan penelitian ini berfokus terhadap kepemimpinan klinis perawat pelaksana. Hasil temuan penelitian ini diharapkan dapat lebih menyempurnakan pelayanan keperawatan yang telah ada saat ini.

\section{METODE PENELITIAN}

Penelitian ini merupakan penelitian deskriptive analytic corelation dengan pendekatan cross sectional. Populasi dalam penelitian ini adalah seluruh perawat pelaksana yang bekerja di ruang rawat inap RSUD Padangsidimpuan dengan jumlah 242 orang dan jumlah sampel yang diperlukan sebanyak 151 perawat.

Ada 5 (lima) jenis instrumen untuk pengumpulan data kepemimpinan klinis, sumber daya perawat, kompetensi perawat, dukungan manajemen dan dukungan lingkungan kerja. Pertama, Clinical Leadership Competence Framework (CLCF) yang dikembangkan oleh National Health Service Leadership Academy pada tahun 2018 merupakan instrumen yang digunakan untuk mengukur kemampuan kepemimpinan klinis. Kuesioner berbentuk skala likert dengan 40 item pernyataan dan semua item pernyataan favorabel. Kedua, instrumen ketersediaan sumber daya perawat diadopsi dari Budiawan pada tahun 2015 berbentuk 
skala likert dengan jumlah sebanyak 43 item pernyataan yang terdiri dari 21 item pernyataan favorabel dan 22 item pernyataan unfavorable. Ketiga, Nurse Competence Scale (NCS) yang dikembangkan oleh Shearer pada tahun 2017 untuk megukur kompetensi perawat pelaksana. Kuesioner berbentuk skala likert dengan 73 item pernyataan dan semua item pernyataan favorable. Keempat, Instrumen mengukur dukungan manajemen dalam praktik keperawatan diadopsi dari Visser \& Comm tahun 2012 telah dimodifikasi dan direvisi dari instrumen yang digunakan oleh Lephala tahun 2006. Kuesioner berbentuk skala likert dengan jumlah sebanyak 22 item pernyataan yang terdiri dari 14 item pernyataan favorabel dan 8 item pernyataan unfavorable. Kelima, instrumen Practice Enviroment Scale of the NWI (PES-NWI) dikembangkan oleh Fernando \& Amaral pada tahun 2012 mengidentifikasi dukungan lingkungan kerja. Kuesioner berbentuk skala likert dengan jumlah sebanyak 31 item pernyataan dan semua item pernyataan favorable.

Kuesioner kepemimpinan klinis, kompetensi, dukungan manajemen dan dukungan lingkungan kerja dalam bahasa Inggris, jadi peneliti menerjemahkan kuesioner ke dalam bahasa Indonesia dan menerjemahkannya kembali ke bahasa Inggris. Selanjutnya dilakukan uji instrumen terhadap 30 perawat pelaksana di RSU Ferdinand Lumban Tobing Sibolga. Berdasarkan hasil validitas SPSS untuk variabel kemampuan kepemimpinan klinis, ketersediaan sumber daya perawat, kompetensi, dukungan manajemen dan dukungan lingkungan kerja, didapatkan bahwa semua item pertanyaan valid dengan $\mathrm{r}$ masing-masing. Masing-masing butir soal $\geq 0,361$. Jadi peneliti menggunakan semua item pertanyaan dari masing-masing variabel saat melakukan penelitian di Ruang Rawat Inap RSUD Padangsidimpuan.

Setelah dilakukan uji validitas, peneliti kemudian melakukan uji reliabilitas. Pengujian reliabilitas dilakukan agar diperoleh pengukuran yang konsisten saat diukur ulang. Hasil reliabilitas output SPSS menunjukkan bahwa semua item pada variabel kemampuan kepemimpinan klinis, ketersediaan sumber daya perawat, kompetensi, dukungan manajemen dan dukungan lingkungan kerja lebih besar dari nilai cronbach alpha ( $\alpha$ ) $5 \%$ yaitu 0,60 , maka alat ukurnya bisa diandalkan.

Peneliti memperhatikan etika penelitian para responden. Oleh karena itu peneliti memberikan penjelasan kepada responden tentang maksud dan tujuan penelitian, proses dan kegunaan penelitian untuk pengembangan ilmu pengetahuan yang akan dilaksanakan. Peneliti memastikan bahwa responden dilindungi dengan memperhatikan aspek kebebasan untuk menentukan bersedia atau tidaknya responden memberikan informasi yang dibutuhkan dalam penelitian. Responden diminta untuk menandatangani informed consent (formulir persetujuan untuk digunakan sebagai responden) secara sukarela dan memastikan kerahasiaan identitas responden yang hanya digunakan untuk kegiatan penelitian. Selama kegiatan penelitian, responden diperlakukan sama dan nama responden diganti dengan kode. Pada saat pendataan, responden diberi kesempatan untuk memilih ruangan yang nyaman agar lebih mudah dalam menjawab pertanyaan.

Analisis data terdiri dari analisis univariat dan bivariat. Analisis univariat disajikan dengan tabel distribusi frekuensi semua variabel, persentase, distribusi frekuensi serta pembahasan deskripsi variabel yang diamati. Sedangkan untuk analisis bivariat menggunakan uji chi square untuk melihat ada tidaknya hubungan antar variabel bebas. 
HASIL PENELITIAN

Karakteristik Perawat Pelaksana

Tabel 1

Distribusi Karakteristik

Perawat Pelaksana

\begin{tabular}{|c|c|c|c|c|}
\hline No & $\begin{array}{c}\text { Karakteristik Perawat } \\
\text { Pelaksana }\end{array}$ & Kategori & $\mathrm{f}$ & $\%$ \\
\hline \multirow{2}{*}{1.} & \multirow{2}{*}{ Usia } & a. Dewasa awal & 142 & 94 \\
\hline & & b. Dewasa menengah & 9 & 6 \\
\hline \multirow{2}{*}{2.} & \multirow{2}{*}{ Jenis Kelamin } & a. Laki-laki & 46 & 30,5 \\
\hline & & b. Perempuan & 105 & 69,5 \\
\hline \multirow{2}{*}{3.} & \multirow{2}{*}{ Pendidikan } & a. Vokasional & 122 & 80,8 \\
\hline & & b. Profesional & 29 & 19,2 \\
\hline \multirow{2}{*}{4.} & \multirow{2}{*}{ Masa Kerja } & a. Baru & 57 & 37,7 \\
\hline & & b. Lama & 94 & 62,3 \\
\hline
\end{tabular}

Berdasarkan tabel 1 memperlihatkan karakteristik perawat pelaksana bahwa hampir seluruhnya perawat pelaksana dengan usia dewasa awal, sebagian besar perawat pelaksana dengan jenis kelamin perempuan, hampir seluruhnya perawat pelaksana dengan jenjang pendidikan vokasional dan sebagian besar responden dengan masa kerja yang lama.

\section{Gambaran Kemampuan Kepemimpinan Klinis Perawat Pelaksana}

Tabel. 2

Distribusi Variabel Kemampuan Kepemimpinan Klinis

Perawat Pelaksana

\begin{tabular}{|c|c|c|c|c|}
\hline No. & $\begin{array}{l}\text { Domain Kemampuan } \\
\text { Kepemimpinan Klinis } \\
\end{array}$ & Kategori & $\mathrm{f}$ & $\%$ \\
\hline \multirow{2}{*}{1.} & \multirow{2}{*}{ Kualitas diri } & Baik & 85 & 56,3 \\
\hline & & Kurang & 66 & 43,7 \\
\hline \multirow{2}{*}{2.} & \multirow{2}{*}{ Kerjasama } & Baik & 90 & 59,6 \\
\hline & & Kurang & 61 & 40,4 \\
\hline \multirow{2}{*}{3.} & \multirow{2}{*}{ Manajemen asuhan keperawatan } & Baik & 81 & 53,6 \\
\hline & & Kurang & 70 & 46,4 \\
\hline \multirow{2}{*}{4.} & \multirow{2}{*}{$\begin{array}{l}\text { Pengembangan layanan } \\
\text { keperawatan }\end{array}$} & Baik & 86 & 57,0 \\
\hline & & Kurang & 65 & 43,0 \\
\hline \multirow{2}{*}{5.} & \multirow{2}{*}{ Kemampuan change agent } & Baik & 89 & 58,9 \\
\hline & & Kurang & 62 & 41,1 \\
\hline \multirow{2}{*}{6.} & Kemampuan kepemimpinan & Baik & 79 & 52,3 \\
\hline & klinis & Kurang & 72 & 47,7 \\
\hline
\end{tabular}

Berdasarkan tabel 2 memperlihatkan secara umum bahwa sebagian besar kemampuan kepemimpinan klinis perawat pelaksana baik. Secara khusus, semua domain dari kemampuan kepemimpinan klinis antara baik dan kurang hampir sama. 


\section{Gambaran Faktor-Faktor Determinan dari Kemampuan Kepemimpinan Klinis}

Tabel. 3

Distribusi Frekuensi Faktor-Faktor Determinan dari Kemampuan Kepimimpinan Klinis

\begin{tabular}{|c|c|c|c|c|}
\hline No. & $\begin{array}{l}\text { Faktor Determinan dari Kemampuan } \\
\text { Kepemimpinan Klinis }\end{array}$ & Kategori & f & $\%$ \\
\hline \multirow[t]{2}{*}{1.} & \multirow{2}{*}{ Ketersediaan sumber daya perawat } & Sesuai & 77 & 51 \\
\hline & & Tidak & 74 & 49 \\
\hline \multirow[t]{2}{*}{2.} & \multirow{2}{*}{ Kompetensi } & Baik & 78 & 51,7 \\
\hline & & Kurang & 73 & 48,3 \\
\hline \multirow[t]{2}{*}{3.} & \multirow{2}{*}{ Dukungan manajemen } & Baik & 76 & 50,3 \\
\hline & & Kurang & 75 & 49,7 \\
\hline \multirow[t]{2}{*}{4} & \multirow{2}{*}{ Dukungan lingkungan kerja } & Baik & 78 & 51,7 \\
\hline & & Kurang & 73 & 48,3 \\
\hline
\end{tabular}

Berdasarkan tabel 3 memperlihatkan bahwa semua faktor determinan dari kemampuan kepemimpinan klinis perawat pelaksana mempunyai frekuensi hampir sama yaitu ketersediaan sumber daya perawat antara sesuai dan tidak, begitu juga kompetensi, dukungan manajemen dan dukungan lingkungan kerja antara baik dan kurang mempunyai frekuensi yang hampir sama.

\section{Hubungan Karakteristik Perawat Pelaksana dengan Kemampuan Kepemimpinan Klinis}

Tabel. 4

Hubungan Karakteristi Perawat Pelaksana dengan Kemampuan Kepemimpinan Klinis

\begin{tabular}{|c|c|c|c|c|c|c|c|c|}
\hline \multirow{3}{*}{$\begin{array}{c}\text { Karakteristik Perawat } \\
\text { Pelaksana }\end{array}$} & \multicolumn{4}{|c|}{$\begin{array}{c}\text { Kemampuan } \\
\text { Kepemimpinan Klinis }\end{array}$} & \multirow{2}{*}{\multicolumn{2}{|c|}{ Total }} & \multirow{3}{*}{$\begin{array}{c}P- \\
\text { value }\end{array}$} & \multirow{3}{*}{$\begin{array}{c}\text { OR } \\
(95 \% \mathrm{CI})\end{array}$} \\
\hline & \multicolumn{2}{|c|}{ Baik } & \multicolumn{2}{|c|}{ Kurang } & & & & \\
\hline & $\mathrm{f}$ & $\%$ & $\mathrm{f}$ & $\%$ & $\mathrm{f}$ & $\%$ & & \\
\hline \multicolumn{9}{|l|}{ Usia } \\
\hline Dewasa awal & 75 & 52,8 & 67 & 47,2 & 142 & 100 & \multirow{2}{*}{0,737} & 1,399 \\
\hline Dewasa menengah & 4 & 44,4 & 5 & 55,6 & 9 & 100 & & $(0,361-5,427)$ \\
\hline \multicolumn{9}{|l|}{ Jenis kelamin } \\
\hline Laki-laki & 16 & 34,8 & 30 & 65,2 & 46 & 100 & \multirow[t]{2}{*}{0,007} & 0,356 \\
\hline Perempun & 63 & 60,0 & 42 & 40,0 & 105 & 100 & & $(0,173-0,732)$ \\
\hline \multicolumn{9}{|l|}{ Pendidikan } \\
\hline Vokasional & 62 & 50,8 & 60 & 49,2 & 122 & 100 & \multirow[t]{2}{*}{0,583} & 0,729 \\
\hline Profesional & 17 & 58,6 & 12 & 41,4 & 29 & 100 & & $(0,321-1,656)$ \\
\hline \multicolumn{9}{|l|}{ Masa kerja } \\
\hline Baru & 27 & 47,4 & 30 & 52,6 & 57 & 100 & \multirow[t]{2}{*}{0,435} & 0,727 \\
\hline Lama & 52 & 55,3 & 42 & 44,7 & 94 & 100 & & $(0,376-1,407)$ \\
\hline
\end{tabular}


Berdasarkan tabel 4 memperlihatkan bahwa hanya karakteristik jenis kelamin yang berhubungan dengan kemampuan kepemimpinan klinis perawat pelaksana. Sedangkan variabel usia, pendidikan dan masa kerja tidak ada hubungan dengan kemampuan kepemimpinan klinis perawat pelaksana.

\section{Faktor - Faktor Determinan Kemampuan Kepemimpinan Klinis Perawat Pelaksana}

Tabel. 5

Faktor-Faktor Determinan Kemampuan Kepemimpinan Klinis Perawat Pelaksana

\begin{tabular}{|c|c|c|c|c|c|c|c|c|}
\hline \multirow{3}{*}{$\begin{array}{c}\text { Faktor-Faktor } \\
\text { Determinan Kemampuan } \\
\text { Kepemimpinan Klinis }\end{array}$} & \multicolumn{4}{|c|}{$\begin{array}{c}\text { Kemampuan } \\
\text { Kepemimpinan Klinis }\end{array}$} & \multirow{2}{*}{\multicolumn{2}{|c|}{ Total }} & \multirow{3}{*}{$\begin{array}{c}P- \\
\text { value }\end{array}$} & \multirow{3}{*}{$\begin{array}{c}\text { OR } \\
(95 \% \mathrm{CI}) \\
\end{array}$} \\
\hline & \multicolumn{2}{|c|}{ Baik } & \multicolumn{2}{|c|}{ Kurang } & & & & \\
\hline & $\mathrm{f}$ & $\%$ & $\mathrm{f}$ & $\%$ & $\mathrm{f}$ & $\%$ & & \\
\hline \multicolumn{9}{|l|}{ Ketersediaan Sumber } \\
\hline \multicolumn{9}{|l|}{ Daya Perawat } \\
\hline Sesuai & 47 & 61,0 & 30 & 39,0 & 77 & 100 & 0,043 & 2,056 \\
\hline Tidak & 32 & 43,2 & 42 & 56,8 & 74 & 100 & & $(1,073-3,939)$ \\
\hline \multicolumn{9}{|l|}{ Kompetensi } \\
\hline Baik & 35 & 44,9 & 43 & 55,1 & 78 & 100 & 0,084 & 0,536 \\
\hline Kurang & 44 & 60,3 & 29 & 39,7 & 73 & 100 & & $(0,281-1,025)$ \\
\hline \multicolumn{9}{|l|}{ Dukungan Manajemen } \\
\hline Baik & 26 & 34,2 & 50 & 65,8 & 76 & 100 & 0,000 & 0,216 \\
\hline Kurang & 53 & 70,7 & 22 & 29,3 & 75 & 100 & & $(0,109-0,429)$ \\
\hline \multicolumn{9}{|l|}{ Dukungan Lingkungan } \\
\hline \multicolumn{9}{|l|}{ Kerja } \\
\hline Baik & 50 & 64,1 & 28 & 35,9 & 78 & 100 & 0,005 & 2,709 \\
\hline Kurang & 29 & 39,7 & 44 & 60,3 & 73 & 100 & & $(1,402-5,235)$ \\
\hline
\end{tabular}

Berdasarkan tabel 5 memperlihatkan bahwa faktor-faktor yang berhubungan dengan kemampuan kepemimpinan klinis perawat pelaksana ada 3 (tiga) yaitu ketersediaan sumber daya perawat, dukungan manajemen dan dukungan lingkungan kerja. Sedangkan kompetensi tidak berhubungan secara signifikan dengan kemampuan kepemimpinan klinis perawat pelaksana di ruang rawat inap RSUD Padangsidimpuan.

\section{Faktor yang paling Dominan Berhubungan dengan Kemampuan Kepemimpinan Klinis Perawat Pelaksana}

Tabel. 6

Analisis Statistik Uji Regresi Logistik tentang Hubungan Jenis Kelamin, Ketersediaan Sumber Daya

Perawat, Kompetensi, Dukungan Manajemen dan Dukungan Lingkungan Kerja dengan Kemampuan Kepemimpinan Klinis Perawat Pelaksana

\begin{tabular}{|c|c|c|c|c|c|c|c|c|}
\hline & Variabel & $\mathrm{B}$ & S.E. & Wald & $\mathrm{df}$ & Sig. & $\operatorname{Exp}(B)$ & $95 \% \mathrm{CI}$ \\
\hline & $\begin{array}{l}\text { Jenis } \\
\text { kelamin }\end{array}$ & 1,048 & 0,417 & 6,299 & 1 & 0,012 & 2,851 & $1,258-6,462$ \\
\hline Step $1^{\mathrm{a}}$ & $\begin{array}{l}\text { Ketersediaan } \\
\text { sumber daya } \\
\text { perawat }\end{array}$ & 0,111 & 0,410 & 0,073 & 1 & 0,787 & 1,117 & $0,500-2,496$ \\
\hline
\end{tabular}




\begin{tabular}{|c|c|c|c|c|c|c|c|c|}
\hline & Kompetensi & $-0,150$ & 0,416 & 0,131 & 1 & 0,718 & 0,860 & $0,380-1,946$ \\
\hline & $\begin{array}{l}\text { Dukungan } \\
\text { Manajemen }\end{array}$ & 1,597 & 0,423 & 14,265 & 1 & 0,000 & 4,940 & $2,156-11,318$ \\
\hline & $\begin{array}{l}\text { Dukungan } \\
\text { Lingkungan } \\
\text { Kerja }\end{array}$ & $-0,826$ & 0,379 & 4,753 & 1 & 0,029 & 0,438 & $0,208-0,920$ \\
\hline & Constant & $-0,782$ & 0,477 & 2,684 & 1 & 0,101 & 0,458 & \\
\hline \multirow{5}{*}{ Step $2^{a}$} & $\begin{array}{l}\text { Jenis } \\
\text { kelamin }\end{array}$ & 1,023 & 0,407 & 6,330 & 1 & 0,012 & 2,783 & $1,254-6,175$ \\
\hline & Kompetensi & $-0,169$ & 0,411 & 0,168 & 1 & 0,682 & 0,845 & $0,377-1,892$ \\
\hline & $\begin{array}{l}\text { Dukungan } \\
\text { Manajemen }\end{array}$ & 1,570 & 0,411 & 14,635 & 1 & 0,000 & 4,809 & $2,151-10,751$ \\
\hline & $\begin{array}{l}\text { Dukungan } \\
\text { Lingkungan } \\
\text { Kerja }\end{array}$ & $-0,804$ & 0,370 & 4,729 & 1 & 0,030 & 0,448 & $0,217-0,924$ \\
\hline & Constant & $-0,706$ & 0,388 & 3,322 & 1 & 0,068 & 0,493 & \\
\hline \multirow{4}{*}{ Step $3^{\mathrm{a}}$} & $\begin{array}{l}\text { Jenis } \\
\text { kelamin }\end{array}$ & 1,028 & 0,407 & 6,383 & 1 & 0,012 & 2,795 & $1,259-6,203$ \\
\hline & $\begin{array}{l}\text { Dukungan } \\
\text { Manajemen }\end{array}$ & 1,499 & 0,369 & 16,497 & 1 & 0,000 & 4,476 & $2,172-9,225$ \\
\hline & $\begin{array}{l}\text { Dukungan } \\
\text { Lingkungan } \\
\text { Kerja }\end{array}$ & $-0,784$ & 0,366 & 4,590 & 1 & 0,032 & 0,456 & $0,223-0,935$ \\
\hline & Constant & $-0,766$ & 0,360 & 4,514 & 1 & 0,034 & 0,465 & \\
\hline
\end{tabular}

Berdasarkan tabel 6 memperlihatkan bahwa kekuatan hubungan yang paling kuat adalah dukungan manajemen dengan nilai $\mathrm{OR}=4,476$. Artinya, dukungan manajemen yang baik berhubungan dengan kemampuan kepemimpinan klinis perawat pelaksana sebesar 4 kali lebih besar dari pada yang dukungan manajemen kurang.

\section{PEMBAHASAN}

\section{Karakteristik Perawat Pelaksana}

Hasil penelitian memperlihatkan karakteristik perawat pelaksana bahwa hampir seluruhnya perawat pelaksana dengan usia dewasa awal, sebagian besar perawat pelaksana dengan jenis kelamin perempuan, hampir seluruhnya perawat pelaksana dengan jenjang pendidikan vokasional dan sebagian besar responden dengan masa kerja yang lama.

Beberapa penelitian mendeskripsikan karakteristik perawat pelaksana diantaranya hasil penelitian Rufaidah et al., (2018) di ruang rawat inap RSUD Dr. H. Soewondo Kendal bahwa sebagian besar perawat pelaksana dengan kategori usia dewasa awal. Ningsih (2018) perawat pelaksana di Ruang Rawat Inap Dewasa Rumah Sakit Muhammadiyah Bandung didapatkan bahwa sebagian besar berjenis kelamin perempuan. Asmuji (2019) juga menunjukkan perawat pelaksana di Ruang Rawat Inap Kelas III RSUD Balung didapatkan sebagian besar dengan pendidikan D III Keperawatan. Sedangkan penelitian Putri et al., (2018) di Ruang Rawat Inap RSUD Bangil bahwa sebagian besar perawat pelaksana dengan masa kerja lama. Berdasarkan uraian di atas, karakteristik perawat pelaksana di ruang rawat inap RSUD Padangsidimpuan memiliki karakteristik yang hampir sama dengan rumah sakit lain. 


\section{Gambaran Kemampuan Kepemimpinan Klinis Perawat Pelaksana}

Hasil penelitian memperlihatkan secara umum bahwa sebagian besar kemampuan kepemimpinan klinis perawat pelaksana baik. Hasil penelitian di Ruang Rawat Inap RSUD Padangsidimpuan memperlihatkan sebagian besar perawat pelaksana mempunyai kemampuan kepemimpinan klinis baik $(52,3 \%)$ dan dari 5 (lima) domain kemampuan kepemimpinan klinis diketahui bahwa sebagian besar kerjasama perawat pelaksana baik $(59,6 \%)$ khususnya terkait hasil angket item kerja diketahui hampir seluruh perawat pelaksana mendengarkan dan memperhatihan kebutuhan orang lain (rekan kerja atau pasien) $(93,4 \%)$. Hal tersebut menunjukkan rasa empati perawat pelaksana terhadap sesama selama melaksanakan pelayanan keperawatan. Menurut hasil penelitian yang dilakukan Butarbutar \& Fathi (2018) di Ruang Rawat Inap RSUPH. Adam Malik Medan didapatkan bahwa sebagian besar perawat memiliki empati baik.

Perawat pelaksana harus memiliki kemampuan kepemimpinan klinis. Studi Mathumo-Githendu (2018) mengidentifikasi bahwa 50\% perawat baru memiliki keterbatasan pemahaman kepemimpinan klinis terkait pengembangan pribadi yang berkelanjutan, bekerja dalam tim, menerapkan pengetahuan dan bukti serta pengembangan layanan keperawatan. Sedangkan Wright (2020) mendeskripsikan bahwa 3-6\% kepemimpinan klinis perawat kurang baik berdampak pada masalah manajemen asuhan keperawatan. Jadi kemampuan kepemimpinan klinis perawat yang belum optimal harus dikembangkan melalui model kepemimpinan klinis.

Hasil penelitian di Ruang Rawat Inap RSUD Padangsidimpuan juga memperlihatkan masih ada perawat pelaksana dengan kemampuan kepemimpinan klinis kurang $(47,7 \%)$ dan hampir setengah perawat pelaksana menyatakan manajemen asuhan keperawatan kurang yaitu 46,4\% khususnya terkait peran dan tanggung jawab. Hal ini sesuai dengan penelitian Jumariah \& Mulyadi (2017) di Kabupaten Bogor memperlihatkan bahwa peran perawat sebagai pemberian asuhan keperawatan kurang baik (40\%) dan sebagian besar peran perawat sebagai edukator tergolong kurang baik (56,7\%). Studi Aprilian (2017) di Ruang Rawat Inap Bedah RSU Bahteramas Sulawesi Tenggara, didapatkan bahwa sebagian besar peran perawat sebagai indikator kurang baik (57,5\%). Peneliti menganalisis peran dan tanggung jawab perawat dapat ditingkatkan melalui penggunaan metode penugasan tim karena mendukung perawat pelaksana dalam memberikan asuhan keperawatan kepada pasien secara utuh.

\section{Gambaran Faktor-Faktor Determinan dari Kemampuan Kepemimpinan Klinis}

Hasil penelitian di Ruang Rawat Inap RSUD Padangsidimpuan memperlihatkan bahwa sebagian besar ketersediaan sumber daya perawat sesuai dan hampir sama bila dilihat dari aspek fisik, psikologis dan waktu. Ketersediaan sumber daya perawat yang sesuai dilihat dari kemampuan perawat dalam mengatasi atau tidak merasakan beban kerja (fisik, psikologis dan waktu) dalam melaksanakan tugasnya selama bekerja di ruangan dan pemberian asuhan keperawatan kepada pasien. Hal ini menunjukkan ketenagaan perawat pelaksana yang ada harus sesuai dengan kuantitas dan kualitas dalam memberikan asuhan keperawatan yang berkualitas. Menurut Ningrum (2019) pengelolaan tenaga keperawatan secara optimal untuk mencapai pelayanan keperawatan yang berkualitas harus mempertimbangkan beban kerja perawat. Rizcarachmakurnia et al., (2017) ketersediaan sumber daya perawat yang cukup dapat memaksimalkan komunikasi dan koordinasi dengan 
profesi kesehatan lainnya dalam pemberian asuhan keperawatan kepada pasien menjadi lebih baik.

\section{Hubungan Karakteristik Perawat Pelaksana dengan Kemampuan Kepemimpinan Klinis}

Hasil penelitian memperlihatkan bahwa hanya karakteristik jenis kelamin yang berhubungan dengan kemampuan kepemimpinan klinis perawat pelaksana. Hal ini sesuai dengan hasil penelitian Anggoro et al., (2019) di RSUD Dr. H. Soewondo Kendal didapatkan bahwa pendidikan tidak berhubungan dengan perilaku caring perawat pelaksana.

Menurut asumsi peneliti bahwa perawat perempuan lebih baik dan berkomitmen dalam melaksanakan pekerjaannya, lebih disiplin dan lebih bertanggung jawab dibanding laki-laki. Perbedaan proporsi jenis kelamin yang besar juga dapat mempengaruhi hasil penelitian ini, dimana di Ruang Rawat Inap RSUD Padangsidimpuan mempunyai proporsi jumlah perawat perempuan lebih banyak dari pada laki-laki, hal tersebut karena perawat laki-laki lebih banyak ditempatkan di ruang instalasi gawat darurat dan ruang operasi.

\section{Faktor - Faktor Determinan Kemampuan Kepemimpinan Klinis Perawat Pelaksana}

Hasil penelitian memperlihatkan bahwa faktor-faktor yang berhubungan dengan kemampuan kepemimpinan klinis perawat pelaksana ada 3 (tiga) yaitu ketersediaan sumber daya perawat, dukungan manajemen dan dukungan lingkungan kerja. Sedangkan kompetensi tidak berhubungan secara signifikan dengan kemampuan kepemimpinan klinis perawat pelaksana di Ruang Rawat Inap RSUD Padangsidimpuan.

Menurut peneliti kompetensi tidak berhubungan dengan kemampuan kepeminpinan klinis perawat pelaksana. Hal ini menunjukkan bahwa perawat pelaksana dapat memiliki kemampuan kepemimpinan klinis dengan baik bukan didasarkan atas kompetensi yang dimiliki perawat pelaksana. Perawat pelaksana dapat menjalin hubungan yang baik dengan kepala ruangan dan perawat pelaksana dapat mendengarkan dan memperhatikan kebutuhan/perasaan pasien atau berempati kepada pasien hal ini disebabkan karena hampir seluruh perawat pelaksana dan pasiennya berasal dari daerah dan suku yang sama. Sehingga relationship dan kepedulian akan tercipta dengan sendirinya dan keadaan tersebut sangat diharapkan untuk mendukung perawat dalam memberikan asuhan keperawatan yang lebih baik kepada pasien.

Selain itu, penilaian kompetensi dalam penelitian ini tidak berdasarkan pengetahuan, sikap dan tindakan. Karena variasi kompetensi perawat pelaksana terlalu luas antara lain dapat dilihat dari aspek kemampuan perawat pelaksana berperan aktif, memberikan pendidikan kesehatan-bimbingan, mengenal masalah, manajemen konflik, tindakan terapeutik, menjamin kualitas, berkontribusi dalam lingkup keperawatan. Aspek tersebut berkaitan perilaku perawat pelaksana dalam memberikan asuhan keperawatan sehingga kompetensi yang dinilai tidak berhubungan dengan kemampuan kepemimpinan klinis perawat pelaksana. 


\section{Faktor yang Paling Dominan Berhubungan dengan Kemampuan Kepemimpinan Klinis Perawat Pelaksana}

Hasil penelitian memperlihatkan bahwa kekuatan hubungan yang paling kuat adalah dukungan manajemen dengan nilai $\mathrm{OR}=4,476$. Artinya, dukungan manajemen yang baik berhubungan dengan kemampuan kepemimpinan klinis perawat pelaksana sebesar 4 kali lebih besar dari pada yang dukungan manajemen kurang. Hasil penelitian ini sejalan dengan penelitian yang dilakukan oleh Wahyudi et al., (2017) adanya hubungan yang bermakna antara dukungan manajemen dengan perilaku caring perawat pelaksana di ruang perawatan interna RSUD Sinjai. Hasil penelitian tersebut juga didukung oleh penelitian Oyoh et al., (2017) menunjukkan bahwa dukungan manajemen sangat berpengaruh terhadap pelaksanaan tugas pokok keperawatan.

Berdasarkan hal tersebut, maka analisis peneliti terhadap perawat pelaksana di Ruang Rawat Inap RSUD Padangsidimpuan memiliki dukungan manajemen yang baik dalam mendukung kemampuan kepemimpinan klinis perawat pelaksana. Namun hasil penelitian juga memperlihatkan bahwa hampir setengah perawat pelaksana menyatakan dukungan manajemen kurang. Hal ini dapat dilihat dari hasil angket memperlihatkan bahwa hampir setengah perawat pelaksana menyatakan dukungan manajemen kurang dalam memberikan pengakuan kepada perawat pelaksana dengan pendidikan yang lebih baik. Adapun hasil angket dari kemampuan kepemimpinan klinis pada domain manajemen asuhan keperawatan memperlihatkan bahwa hampir setengah perawat pelaksana dengan peran dan tanggung jawab yang kurang. Jadi dukungan manajemen berupa pengakuan yang kurang diberikan kepada perawat pelaksana menyebabkan perawat pelaksana kurang dalam melaksanakan peran dan tanggungjawabnya.

Oleh karena itu, peneliti menyarankan kepada pihak manajerial RSUD Padangsidimpuan untuk memberikan pengakuan berupa umpan balik bagi perawat pelaksana yang telah selesai menjalankan tugasnya sehingga apabila ada kekurangan terhadap pekerjaannya akan diketahui dan segera diperbaiki. Penelitian ini memberikan deskripsi kemampuan kepemimpinan klinis di RSUD Padangsidimpuan.

\section{SIMPULAN}

Ada hubungan yang signifikan antara ketersediaan sumber daya perawat, dukungan lingkungan kerja dan dukungan manajemen dengan kemampuan kepemimpinan klinis perawat pelaksana. Sedangkan kompetensi tidak ada hubungan yang signifikan dengan kemampuan kepemimpinan klinis perawat pelaksana. Faktor yang paling dominan berhubungan dengan kemampuan kepemimpinan klinis perawat pelaksana adalah dukungan manajemen.

\section{SARAN}

Berdasarkan hasil penelitian ini, diharapkan perawat lebih menunjukkan dan secara kontinyu meningkatkan kemampuan kepemimpinan klinis dan mengevaluasi efektifitas kemampuan kepemimpinan klinisnya sesuai dengan kerangka clinical leadership competency framework. Sedangkan pihak manajerial rumah sakit dapat menambah kebijaksan misalnya mengirimkan perwakilannya untuk mengikuti seminar-seminar atau pelatihan tentang pengembangan ilmu keperawatan khususnya terkait kemampuan kepemimpinan klinis. 


\section{DAFTAR PUSTAKA}

Anggoro, W. T., Aeni, Q., \& Istioningsih, I. (2019). Hubungan Karakteristik Perawat dengan Perilaku Caring. Jurnal Keperawatan Jiwa, 6(2), 98. https://doi.org/10.26714/jkj.6.2.2018.98-105

Aprilian, W. T. (2017). Tinjauan Peran Perawat Sebagai Edukator dalam Memberikan Pelayanan Keperawatan pada Pasien Post Op di Ruang Rawat Inap Bedah RSU Bahteramas Provinsi Sulawesi Tenggara. Politeknik Kesehatan Kendari. http://repository.poltekkes-kdi.ac.id/353/

Asmuji, A. (2019). Faktor-Faktor yang Berhubungan dengan Kapasitas Kerja terhadap Perilaku Caring Perawat di RSUD Balung. Sekolah Tinggi Ilmu Kesehatan Maharani. 257-264. http://jurnal.unmuhjember.ac.id/index.php/psn/article/download/1754/1441

Boamah, S. A. (2019). Emergence of Informal Clinical Leadership as a Catalyst for Improving Patient Care Quality and Job Satisfaction. Journal of Advanced Nursing, 75(5), 1000-1009. https://doi.org/10.1111/jan.13895

Budiawan, I. N. (2015). Hubungan Kompetensi, Motivasi dan Beban Kerja Perawat Pelaksana dengan Kinerja Perawat di Ruang Rawat Inap Rumah Sakit Jiwa Propinsi Bali. Public Health and Preventive Medcine Archive, 3(2), 179-187. https://media.neliti.com/media/publications/21503.pdf

Butarbutar, R., \& Fathi, A. (2018). Gambaran Empati Perawat dalam Memberikan Asuhan Keperawatan di Ruang Rawat Inap Rsup H. Adam Malik. TALENTA Conference Series: Tropical Medicine, 1(1), 1-5. https://doi.org/10.32734/tm.v1i1.29

Gatti, P., Ghislieri, C., \& Cortese, C. G. (2017). Relationships between Followers' Behaviors and Job Satisfaction in a Sample of Nurses. PLoS ONE, 12(10), 1-17. https://doi.org/10.1371/journal.pone.0185905

Health Education England (HEE), N. H. S. (NHS). (2018). Health Research Authoritydecisiontoolsorguk. Consent and Participant Information Sheet. Retrieved from https://www.gov.uk/government/uploads/system/uploads/attachment_data/file/55994 0/HEE

Jumariah, T., \& Mulyadi, B. (2016). Peran Perawat dalam Pelaksanaan Perawatan Kesehatan Masyarakat (Perkesmas). Jurnal Ilmiah Ilmu Keperawatan Indonesia, 7(1), 182-188. http://journals.stikim.ac.id/index.php/jiiki/article/view/233

Lai, A. L., Millet, J. K., Daniel, S., Freed, J. H., \& Whittaker, G. R. (2020). Since January 2020 Elsevier has Created a COVID-19 Resource Centre with Free Information in English and Mandarin on the Novel Coronavirus COVID- Company's Public News and Information Website. Elsevier Hereby Grants Permission to Make All its COVID-19-r. The Lancet, 395(April), 1315

Mathumo-Githendu, G. W. (2018). Clinical Leadership Competency: Newly Qualified Nurses' Understanding and Needs. WireDSpace Retrieved from http://wiredspace.wits.ac.za/handle/10539/25372

Mianda, S., \& Voce, A. (2018). Developing and Evaluating Clinical Leadership Interventions for Frontline Healthcare Providers: A Review of the Literature 11 Medical and Health Sciences 1117 Public Health and Health Services. BMC Health Services Research, 18(1), 1-15. https://doi.org/10.1186/s12913-018-3561-4 
Mianda, S., \& Voce, A. S. (2017). Conceptualizations of Clinical Leadership: A Review of the Literature. Journal of Healthcare Leadership, 9, 79-87. https://doi.org/10.2147/JHL.S143639

National Health Service Leadership Academy. (2018). Self Assessment tool: TET-SAT. 112. Retrieved from https://url2.cl/mVzCF

NHS Improvement. (2019). Clinical Leadership - A Framework for Action: A Guide for Senior Leaders on Developing Professional Diversity at Board Level. NHS Improvement. $\quad$ Retrieved from https://improvement.nhs.uk/documents/3702/Clinical_leadership_framework_Jan201 9.pdf

Nieuwboer, M. S., Van Der Sande, R., Van Der Marck, M. A., Olde Rikkert, M. G. M., \& Perry, M. (2019). Clinical Leadership and Integrated Primary Care: A Systematic Literature Review. European Journal of General Practice, 25(1), 7-18. https://doi.org/10.1080/13814788.2018.1515907

Ningrum, R. K. (2019). Analisis Kebutuhan Perawat Pelaksana Berdasarkan Metode Workload Indicator Staff Need (WISN) dalam Upaya Meningkatkan Kualitas Pelayanan di Instalasi Gawat Darurat Lantai I RSUP Dr. Hasan Sadikin Bandung. Universitas Pasundan. http://repository.unpas.ac.id/47409/

Ningsih, D. M. (2018). Faktor-Faktor yang Berhubungan dengan Perilaku Caring Perawat dalam Memberikan Spiritual Care Islam di Ruang Rawat Inap Rumah Sakit Muhammadiyah Bandung. Jurnal Keperawatan 'Aisyiyah, 5(6), 79-98. https://journal.stikes-aisyiyahbandung.ac.id/index.php/jka/article/view/82

Oyoh, O., Somantri, I., \& Sekarwana, N. (2017). Pengalaman Perawat dalam Pelaksanaan Sistem Pemberian Pelayanan Keperawatan Profesional di RSUD Cibabat: Studi Fenomenologi Nurse Experience in the Implementation of Professional Nursing Services System at Cibabat Hospital : Phenomenology Study. Jurnal Keperawatan Padjadjaran, 5(3), 329-339. http://jkp.fkep.unpad.ac.id/index.php/jkp/article/view/678

Putri, I. I., Nawangsari, H., \& Maunaturrah, A. (2018). Hubungan antara Tingkat Stres Kerja Perawat dengan Perilaku Caring Perawat. Sekolah Tinggi Ilmu Kesehatan Insan Cendekia Medika. http://repo.stikesicmejbg.ac.id/1387/2/14321014920INSYIRA\%20IMANIA\%20PUTRI\%20SKRIPSI.pdf

Rizcarachmakurnia, N., Wigati, P. A., \& Sriatmi, A. (2017). Analisis Beban Kerja dan Kebutuhan Tenaga Perawat di Puskesmas Poncol Kota Semarang. Jurnal Kesehatan Masyarakat, $5(3)$, 26-33. https://ejournal3.undip.ac.id/index.php/jkm/article/view/17163

Rufaidah, S., Aeni, Q., \& Istioningsih, I. (2018). Hubungan Perilaku Caring Perawat Dengan Los (Length Of Stay) pada Pasien Rawat Inap. Jurnal Keperawatan, 10(1), 44-52. http://journal.stikeskendal.ac.id/index.php/Keperawatan/article/download/67/

Schwendimann, R., Blatter, C., Dhaini, S., Simon, M., \& Ausserhofer, D. (2018). The Occurrence, Types, Consequences and Preventability of in-Hospital Adverse Events A Scoping Review. BMC Health Services Research, 18(1), 1-13. https://doi.org/10.1186/s12913-018-3335-z 
Shearer, J. (2016). Examining Content Validity of the Nurse Competence Scale in the United States. ProQuest Dissertations and Theses, 237. Retrieved from https://search.proquest.com/docview/1864669683? accountid=17242

Stanley, D., Blanchard, D., Hohol, A., Hutton, M., \& McDonald, A. (2017). Health Professionals' Perceptions of Clinical Leadership. A Pilot Study. Cogent Medicine, 4(1), 1-16. https://doi.org/10.1080/2331205x.2017.1321193

Vinu-Job, R., Choihoong, M., \& Iringan, A. (2020). Pan London Clinical Leadership. http://www.londonneonatalnetwork.org.uk/about-us/nursing-workforce-andeducation/

Wahyudi, S, E., Ashar, M. U., \& Syisnawati. (2017). Faktor-Faktor Yang Berhubungan Dengan Perilaku Caring Perawat Di Ruang Perawatan Interna. Jurnal of Islamic Nursing, 2(2), 83-92. http://repositori.uin-alauddin.ac.id/4967/

Wright, V. D. (2020). Registered Nurses 'Assessment of Clinical Leadership Knowledge and Competence. Walden University. https://scholarworks.waldenu.edu/dissertations/8351/ 